Diabetologia (1990) 33: 549-556

\title{
Reduction of insulin resistance by combined kidney-pancreas transplantation in Type 1 (insulin-dependent) diabetic patients
}

\author{
L. Luzi ${ }^{1}$, A.Secchi ${ }^{1}$, F. Facchini ${ }^{1}$, A.Battezzati ${ }^{1}$, C.Staudacher ${ }^{2}$, D. Spotti ${ }^{1}$, R. Castoldi ${ }^{2}$, G.Ferrari ${ }^{2}$, V. Di Carlo ${ }^{2}$ \\ and G.Pozza \\ Departments of ${ }^{1}$ Internal Medicine and ${ }^{2}$ Surgery, Istituto Scientifico San Raffaele, University of Milan, Milan, Italy
}

\begin{abstract}
Summary. To evaluate the effect of combined kidney and pancreas transplantation on insulin action and glucose metabolism, 15 Type 1 (insulin-dependent) diabetic patients who were undergoing combined kidney-pancreas transplantation were studied before transplantation by means of the euglycaemic hyperinsulinaemic clamp technique combined with $3-{ }^{3} \mathrm{H}$-glucose infusion and indirect calorimetry. Nine of the original 15 patients were studied again after four months and six after 12 months, successful combined kidney-pancreas transplantation with the same experimental protocol. Nine volunteers formed the group of normal subjects. Combined kidney-pancreas transplantation normalised hepatic glucose production and reduced peripheral insulin resistance in Type 1 diabetic uraemic patients, despite chronic immunosuppressive therapy. To further evaluate the hypothesis that residual insulin resistance was due to chronic steroid therapy, 11 additional subjects with chronic uveitis (six of whom were treated with only prednisone, and five treated only with cyc-
\end{abstract}

losporin) underwent the same protocol demonstrating a normal hepatic glucose production. The insulin-stimulated peripheral glucose uptake was reduced in the prednisonetreated group, but normal in cyclosporin-treated subjects. Four additional diabetic patients with a kidney transplant were also studied. They showed a peripheral insulin sensitivity intermediate between diabetic uraemic patients and patients after combined transplant. We conclude that shortterm (one year) combined kidney-pancreas transplantation improves glucose metabolism by restoring normal rates of hepatic glucose production and reducing peripheral insulin resistance; chronic steroid therapy is the major determinant of residual reduced insulin action. Both kidney and pancreas substitution play a role in reducing peripheral insulin resistance.

Key words: Insulin resistance, pancreas transplantation, indirect calorimetry.
In recent years pancreas transplant alone, or combined with kidney transplant, has become an innovative surgical practice in the treatment of Type 1 (insulin-dependent) diabetes mellitus with late complications, especially end stage renal failure [1-5]. The different surgical approaches have all been effective, in the short-term, correcting both hyperglycaemia [3-7] and the major metabolic alterations usually present in Type 1 diabetes [5, 7-8]. However, little information is available on the effect of endocrine pancreas function substitution on long-term metabolic control [9-11] and on insulin resistance, associated with both Type 1 and Type 2 (non-insulin-dependent) diabetes. Indeed, one of the major inconveniences in the long-term management of transplanted patients is the need to continue chronic immunosuppressive therapy [12]. Among the drugs used for immunosuppression, prednisone is the one which may antagonize peripheral insulin action [13$15]$, causing the development of insulin resistance. We have studied the effect of combined kidney-pancreas transplantation on "in vivo" insulin action, both at the liver and at peripheral sites, by means of the tritiated glu- cose technique, combined with the euglycaemic insulin clamp and indirect calorimetry. In addition, we have studied the effect of chronic therapy with steroids and cyclosporin A on glucose metabolism in subjects with localized ocular diseases (but no systemic disease), as a control group for kidney-pancreas transplanted patients.

\section{Subjects and methods}

\section{Subjects}

Since January, 1986, 15 subjects ( 7 females, 8 males) have had combined kidney-pancreas transplantation in our institution. All the subjects had Type 1 diabetes (duration of diabetes $=24 \pm 4$ years) combined with end stage renal failure (duration of haemodialysis $=22 \pm 4$ months) at the time of transplantation. In Table 1 the clinical and laboratory characteristics are summarized before and after $4 \pm 1$ and $12 \pm 2$ months of combined kidney-pancreas transplantation, together with the drugs taken by the study subjects after surgery, as well as the relevant data in all the groups of patients described below. 
Table 1. Clinical and laboratory data before and after ( 4 and 12 months) combined kidney and pancreas transplantation and of the four different control groups. All the values represent mean \pm SEM; samples were taken in the fasting, basal condition

\begin{tabular}{|c|c|c|c|c|c|c|c|c|}
\hline Groups & & $\begin{array}{l}1 \text { a } \\
\text { Type } 1 \text { dia- } \\
\text { betic patients } \\
\text { (pre-tpx) }\end{array}$ & $\begin{array}{l}1 \mathrm{~b} \\
\text { Type } 1 \text { dia- } \\
\text { betic patients } \\
(4 \text { months } \\
\text { post-tpx) }\end{array}$ & $\begin{array}{l}1 \mathrm{c} \\
\text { Type } 1 \text { dia- } \\
\text { betic patients } \\
\text { (12 months } \\
\text { post-tpx) }\end{array}$ & $\begin{array}{l}2 \\
\text { Normal } \\
\text { subjects }\end{array}$ & $\begin{array}{l}3 \\
\text { Control sub- } \\
\text { jects (long- } \\
\text { term steroid } \\
\text { therapy) }\end{array}$ & $\begin{array}{l}4 \\
\text { Control sub- } \\
\text { jects (long- } \\
\text { term cyclo- } \\
\text { sporin therapy) }\end{array}$ & $\begin{array}{l}5 \\
\text { Type } 1 \text { dia- } \\
\text { betic patients } \\
\text { (isolated kid- } \\
\text { ney tpx) }\end{array}$ \\
\hline Number & & 15 & 12 & 12 & 9 & 6 & 5 & 4 \\
\hline Age & (years) & $36 \pm 4$ & $36 \pm 5$ & $38 \pm 5$ & $36 \pm 3$ & $42 \pm 5$ & $43 \pm 7$ & $35 \pm 4$ \\
\hline Weight & $(\mathrm{kg})$ & $59 \pm 6$ & $59 \pm 5$ & $64 \pm 5$ & $66 \pm 6$ & $67 \pm 7$ & $68 \pm 8$ & $65 \pm 5$ \\
\hline $\begin{array}{l}\text { Blood pres- } \\
\text { sure (systolic/ } \\
\text { diastolic) }\end{array}$ & $(\mathrm{mmHg})$ & $165 \pm 6 / 86 \pm 6^{c}$ & $150 \pm 8 / 85 \pm 9$ & $152 \pm 9 / 86 \pm 3$ & $125 \pm 5 / 82 \pm 3$ & $130 \pm 5 / 85 \pm 5$ & $142 \pm 5 / 86 \pm 3$ & $150 \pm 8 / 88 \pm 6$ \\
\hline Blood pH & $(\mathrm{pHU})$ & $7.29 \pm 0.04^{\mathrm{a}}$ & $7.40 \pm 0.02$ & $7.39 \pm 0.03$ & $7.41 \pm 0.02$ & $7.40 \pm 0.02$ & $7.40 \pm 0.01$ & $7.40 \pm 0.01$ \\
\hline Insulindose & (U/die) & $40 \pm 4$ & - & - & - & - & - & $46 \pm 3$ \\
\hline Plasma HPO4 & $(\mathrm{mmol} / \mathrm{l})$ & $1.74 \pm 0.20^{\mathrm{a}}$ & $1.03 \pm 0.10$ & $1.00 \pm 0.12$ & $0.80 \pm 0.10$ & $0.95 \pm 0.10$ & $0.92 \pm 0.15$ & $0.95 \pm 0.22$ \\
\hline $\begin{array}{l}\text { Nitrogen } \\
\text { excretion }\end{array}$ & $(\mathrm{mg} / \mathrm{min})$ & $10.4 \pm 0.7^{\mathrm{a}}$ & $6.8 \pm 0.4$ & $7.1 \pm 0.5$ & $8.4 \pm 0.5$ & $8.0 \pm 0.6$ & $7.9 \pm 0.5$ & $8.2 \pm 0.3$ \\
\hline $\begin{array}{l}\text { Plasma } \\
\text { C-peptide }\end{array}$ & (ng/mi) & $0.08 \pm 0.03^{\mathrm{b}}$ & $3.70 \pm 0.80^{\mathrm{d}}$ & $2.04 \pm 0.36$ & $1.80 \pm 0.20$ & $2.20 \pm 0.035$ & $1.85 \pm 0.15$ & $0.05 \pm 0.01^{\mathrm{b}}$ \\
\hline Plasma GH & $(\mathrm{pmol} / 1)$ & $432 \pm 101^{\mathrm{a}}$ & $98.4 \pm 9.2$ & $56.6 \pm 23$ & $55.2 \pm 9.2$ & $99.0 \pm 20.5$ & $94.2 \pm 15.5$ & $85.3 \pm 18.4$ \\
\hline Prednisone & (mg/die) & - & $10 \pm 1$ & $10 \pm 1$ & - & $12 \pm 2$ & - & $10 \pm 1$ \\
\hline Cyclosporin & $\begin{array}{l}\left(\mathrm{mg} \cdot \mathrm{kg}^{-1}\right. \\
\left.\cdot \mathrm{die}^{-1}\right)\end{array}$ & - & $8.6 \pm 0.7$ & $5.6 \pm 1.5$ & - & - & $6.0 \pm 1.4$ & $5.5 \pm 0.3$ \\
\hline Azathioprine & $\left(\mathrm{mg} \cdot \mathrm{die}^{-1}\right)$ & - & $85.7 \pm 6.0$ & $58.3 \pm 6.5$ & - & - & - & $50.2 \pm 6.8$ \\
\hline
\end{tabular}

Four different control groups were studied, indicated as groups 2 (normal subjects), 3 (control subjects on long-term steroid therapy), 4 (control subjects on long-term cyclosporin therapy) and 5 (Type 1 diabetic subjects with isolated kidney transplantation). Informed consent was obtained from all the subjects before their participation in the study. The study protocol was approved by the local ethical committee.

\section{Surgical approach and immunosuppression}

Organs for transplantation were obtained from cadaveric donors. Kidney and pancreas transplantation was performed as previously described [3]. In particular, the transplanted pancreas was anastomosed with the left iliac artery and vein of the recipient [3]. All of the subjects studied after transplantation were on the following immunosuppressive treatment for at least 30 days before the first of the two studies: azathioprine $1 \mathrm{mg} \cdot \mathrm{kg}^{-1} \cdot \mathrm{die}^{-1}$; cyclosporin $6 \mathrm{mg}$. $\mathrm{kg}^{-1} \cdot \mathrm{die}^{-1}$; prednisone $10 \mathrm{mg} / \mathrm{die}$.

\section{Experimental protocol (Fig.1)}

All tests were performed in the postabsorptive state beginning at 08.00 hours, following a $12 \mathrm{~h}$ overnight fast. A polyethylene catheter was inserted in an antecubital vein for the infusion of all test substances. A second catheter was inserted retrogradely in a wrist vein and advanced to the dorsum of the hand for blood sampling. The hand was kept in a heated box at $70^{\circ} \mathrm{C}$ to ensure arterialization of the venous blood [16]. In each study protocol a prime-continuous infusion of $3-{ }^{3} \mathrm{H}$-glucose (New England Nuclear, Boston, Mass., USA) was administered (a priming dose of $30 \mu \mathrm{Ci}$ followed by a continuous infusion of $0.25 \mu \mathrm{Ci} / \mathrm{min}$ ). Blood for the determination of the $3-{ }^{3} \mathrm{H}$ glucose specific activity was drawn every $15 \mathrm{~min}$ for the first $90 \mathrm{~min}$ and every $5 \mathrm{~min}$ for the last $30 \mathrm{~min}$ of the basal state. Blood for the determination of plasma metabolites and hormone concentrations was drawn at $15-30 \mathrm{~min}$ intervals during the basal period and throughout the study.

In all studies the rates of carbon dioxide production and oxygen consumption were measured by continuous indirect calorimetry as previously described $[17,18]$. Briefly, a transparent plastic ventilated hood was placed over the head of the subject and made airtight around the neck. A slight negative pressure was maintained in the hood to avoid the loss of expired air. The carbon dioxide content of expired air was continuously measured by an infrared carbon dioxide analyser (model LB-2, Sensor Medics, Anaheim, Calif., USA). The oxygen content of expired air was continuously measured by an oxygen analyser (model Beckman OM 11, Anaheim, Calif., USA).

All the subjects on haemodialysis were studied $18-22 \mathrm{~h}$ after the end of the last dialysis session (three sessions per week). On the day prece ding the study, urea plasma clearance was quantified during the standard dialysis session ( $4 \mathrm{~h}$ duration), and the blood urea clearance rate, added to the residual urinary urea excretion rate, was used as an estimate of whole body protein oxidation. Of the 15 candidates for combined kidney-pancreas transplantation nine agreed to participate twice in the study protocol: the second study was performed 
STUDY 10

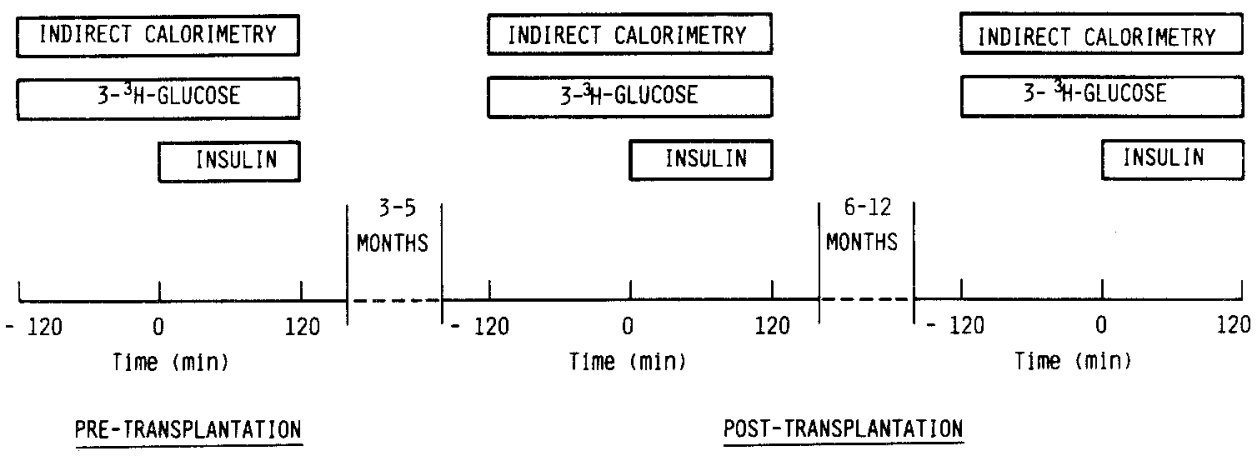

STUDY $1 \mathrm{C}$ 120 at least three months (and no more than five months) after surgery (study $1 \mathrm{~b}$ ); six of the nine subjects who participated in studies $1 \mathrm{a}$ and $1 \mathrm{~b}$ agreed to participate also in the third study protocol (study $1 \mathrm{c}$ ) which took place $6-12$ months after study $1 \mathrm{~b}$ (10-17 months after surgery).

Study 1 a. Insulin clamp (Type 1 diabetic uraemic patients before transplantation).

Fifteen Type 1 diabetic uraemic subjects participated in the first study protocol. They had a mean fasting plasma glucose concentration of about $7.30-8.42 \mathrm{mmol} / \mathrm{l}$ during the three days preceding the study. The mean $\mathrm{HbA}_{1 c}$ concentration was $8.9 \pm 0.5 \%$. All subjects followed weight maintaining diet containing at least $250 \mathrm{~g}$ of carbohydrate per day and between 40 and $80 \mathrm{~g}$ protein per day for at least 7 days prior to the study. All the patients were admitted on the day before the study, at the end of a haemodialysis session. The last doses of intermediate- and short-acting insulin were administered s.c. $36 \mathrm{~h}$ and $18 \mathrm{~h}$ before the morning of the study ( 08.00 hours), respectively. Blood glucose was measured every $2 \mathrm{~h}$ starting at 17.00 hours on the day before the study; a small bolus ( $3-4 \mathrm{U}$ ) of regular insulin was administered i.v. when necessary (blood glucose $>15 \mathrm{mmol} / \mathrm{l}$ ). At 24.00 hours on the day before the study $(8 \mathrm{~h}$ before the start of the 3 ${ }^{3} \mathrm{H}$-glucose infusion), diabetic uraemic subjects received a basal i.v. insulin infusion at the rate of $4.0 \pm 0.3 \mathrm{mU} \cdot \mathrm{m}^{2-1} \cdot \mathrm{min}^{-1}$ to maintain the plasma glucose concentration between $6.10-8.45 \mathrm{mmol} / \mathrm{l}$. The low dose insulin infusion was continued until the start of the insulin clamp. After a 120 min equilibration period an insulin clamp study was performed as previously described $[18,19]$. A prime-continuous infusion of crystalline human insulin (Novo, Actrapid HM $40 \mathrm{U} / \mathrm{ml}$ Copenhagen, Denmark) was administered at the rate of $40 \mathrm{mU} \cdot \mathrm{m}^{2-}$ ${ }^{1} \cdot$ min $^{-1}$ for 120 min to achieve and maintain an increase in plasma insulin concentration of approximately $65 \mu \mathrm{U} / \mathrm{ml}$, by means of a Harvard infusion pump (Model 975 A, Millis, Mass., USA). The plasma glucose concentration was kept constant at the basal level by determining the plasma glucose concentration at 5 min intervals and periodically adjusting a $20 \%$ glucose infusion based on a negative feed-back principle $[18,19]$. The glucose solution was infused by means of a Harvard infusion system (Model 2990, Millis). Blood samples for the determination of the $3-{ }^{3} \mathrm{H}$-glucose specific activity were drawn every $10 \mathrm{~min}$ throughout the study. A total amount of $90 \mathrm{ml}$ of whole blood was drawn during this study protocol.

Study $1 b$ and study $I c$. Insulin clamp (patients after combined kidney-pancreas transplantation; transplant duration $4 \pm 1$ and $12 \pm 2$ months, respectively).

Nine of the 15 subjects who participated in Study 1 a and three additional subjects, received a repeat insulin clamp four months after transplantation; the experimental protocol was similar to that described in study 1 a with the exception that after transplantation the subjects did not require any insulin the night prior to the study. Six of the subjects who participated in study $1 \mathrm{~b}$ (and $1 \mathrm{a}$ ) were studied again after 6-12 months with the same experimental protocol, to assess the effects of both long-term immunosuppressive therapy and of long-lasting normoglycaemia on insulin sensitivity. Six additional subjects who underwent kidney-pancreas transplantation in the period preceding the start of this longitudinal protocol were included in study $1 \mathrm{c}$ and studied with the previously described proto$\mathrm{col}$. The daily dose of immunosuppressive drugs in studies $1 \mathrm{~b}$ and $1 \mathrm{c}$ was administered at 12.00 hours, at the end of the test.

Study 2. Insulin clamp (normal subjects).

Nine normal volunteers received a $120 \mathrm{~min}$ euglycaemic insulin clamp $\left(40 \mathrm{mU} \cdot \mathrm{m}^{2-1} \cdot \mathrm{min}^{-1}\right)$ in combination with indirect calorimetry and $3-{ }^{3} \mathrm{H}$-glucose as described previously for study $1 \mathrm{a}$.

Study 3. Insulin Clamp (subjects on long-term steroid therapy).

An additional control group of six subjects (without a family history of diabetes) on long-term steroid therapy (Table 1) was studied with the same modalities as in studies 1 and 2 to assess the effect of a long-term steroid administration (comparable to that of transplanted subjects) on glucose metabolism. All the subjects were on steroid therapy for at least four months, and they were matched for sex and BMI with the kidney-pancreas transplanted patients. Five of them had chronic uveitis, and one, had Behçet's disease.

Study 4. Insulin clamp (subjects on long-term cyclosporin therapy).

Five additional subjects with chronic uveitis without a family history of diabetes on long-term therapy with cyclosporin A were investigated with the same modalities as in studies 1-3 to assess the effect of long-term cyclosporin therapy (per se) on glucose metabolism and insulin resistance. All the subjects received $6 \mathrm{mg} \cdot \mathrm{kg}^{-1} \cdot \mathrm{day}^{-1}$ of the drug for at least four months.

Study 5. Insulin clamp (Type 1 diabetic subjects after isolated kidney transplantation).

Four Type 1 diabetic subjects after isolated kidney transplantation were used as a last control group. All the subjects were insulin dependent diabetic patients with a fasting plasma glucose of $7.8 \pm 0.2 \mathrm{mmol} / 1$ and an $\mathrm{HbA}_{1 \mathrm{c}}$ of $8.5 \pm 0.2 \%$. The long-term immunosuppressive therapy was similar to patients of study $1 \mathrm{~b}$ and $1 \mathrm{c}$ (Table 1). The study protocol was similar to that of Type 1 diabetic uraemic patients included in study 1 a.

\section{Calculations}

Hepatic glucose production in the basal state was determined by dividing the $3{ }^{3} \mathrm{H}$-glucose infusion rate by the steady state plateau of $3-{ }^{3} \mathrm{H}$-glucose specific activity, achieved during the last $30 \mathrm{~min}$ of the basal period. Since a non-steady state existed after insulin administration in the plasma glucose specific activity, the rate of glucose turnover was calculated using Steele's equations in their derivative form [20]. During the insulin clamp, the rate of hepatic glucose production was calculated by subtracting the glucose infusion rate from the rate of glucose appearance measured with the isotope tracer technique. Occasionally, small negative numbers were observed in 
Table 2. Plasma concentrations of glucose, non-esterified fatty acids (NEFA), free insulin (IRI) and glucagon (IRG) in the basal state (mean \pm SEM of samples taken in the last $30 \mathrm{~min}$ of the basal period) and determinations made during insulin clamp (mean \pm SEM of samples taken in the 60-120 min period) in all study groups

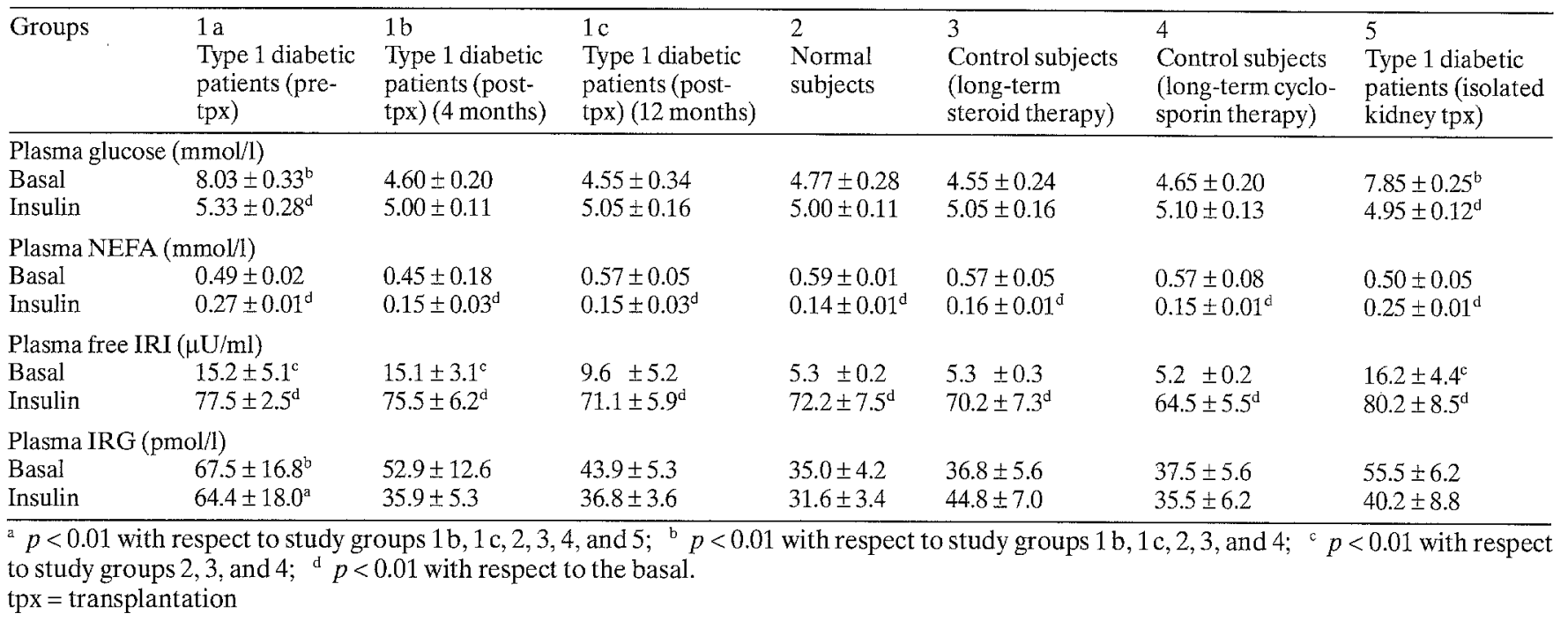

the control subjects; in such instances the hepatic glucose production was assumed to be zero. In the basal period, total body glucose disappearance was calculated from the $3-{ }^{3} \mathrm{H}$-glucose data. During insulin/glucose infusion total body glucose uptake was determined by adding the rate of residual hepatic glucose production to the exogenous glucose infusion rate. Since urinary glucose loss was negligible in all the study groups, the total body glucose disappearance corresponded to tissue glucose uptake.

The rates of glucose and lipid oxidation were calculated in the basal state and during insulin infusion from the non protein respiratory quotient [21], using the tables of Lusk [22] and assuming protein oxidation to be fairly constant during the $4 \mathrm{~h}$ study. Nonoxidative glucose disposal was calculated subtracting the glucose oxidation rate from the tissue glucose disposal. Protein oxidation was estimated from urinary nitrogen excretion [21,23].

Values for rates of total body glucose utilization and hepatic glucose production represent the mean rates during the last $30 \mathrm{~min}$ of the basal state and during the $0-60$ and $60-120$ min periods of the insulin clamp.

\section{Analytical procedures}

Urine and plasma glucose concentrations were determined by a differential-pH method as previously described [24]. Plasma non-esterified fatty acids (NEFA) were measured by an automatized enzymatic colorimetric method (Wako Chemicals GmbH, Neuss, West Germany) [25]; plasma insulin [8], free insulin [8], C-peptide [8], glucagon [8], and growth hormone [41] were measured by standard RIA as previously described. Blood cyclosporin concentration was measured by RIA utilizing monoclonal antibodies to recognize native cyclosporin A (Cyclo-Trac, Incstar Co., Stillwater, Minn., USA) [42]. Plasma $3{ }^{3} \mathrm{H}$-glucose specific radioactivity was measured in duplicate on the supernatants of $\mathrm{Ba}(\mathrm{OH})_{2} / \mathrm{ZnSO}_{4}$ precipitates, after total evaporation to eliminate ${ }^{3} \mathrm{H}$-water (Somogyi's method) [26]. Urinary nitrogen excretion was measured by Kjeldhal's method [23].

\section{Statistical analysis}

All data are presented as mean \pm SEM. Comparisons between the basal and the insulin-stimulated state within a group were performed using the Student's $t$-test for paired data. Comparisons between different groups were performed using both the analysis of variance and the Student's $t$-test.

\section{Results}

\section{Plasma metabolite and hormone concentrations}

(Tables 1 and 2)

Plasma glucose concentration was $8.03 \mathrm{mmol} / 1$ in Type 1 diabetic uraemic subjects and $7.85 \mathrm{mmol} / 1$ in Type 1 diabetic patients with isolated kidney transplantation when the $3-{ }^{3} \mathrm{H}$-glucose was started, and remained fairly constant until the start of insulin infusion. When insulin was started $\left(40 \mathrm{mU} \cdot \mathrm{m}^{2-1} \cdot \mathrm{min}^{-1}\right)$ the plasma glucose concentration was allowed to decrease to euglycaemic values, where it was clamped for an additional $120 \mathrm{~min}$. During the euglycaemic insulin clamp the plasma glucose concentration was maintained between 4.90 and $5.40 \mathrm{mmol} / \mathrm{l}$ in all groups with a coefficient of variation of $3 \pm 1 \%$ (Table 2 ).

Basal plasma NEFA's were not statistically different in all groups; following insulin infusion the decrease of plasma NEFA's was lower in study $1 \mathrm{a}$ and 5 compared to studies $1 \mathrm{~b}, 1 \mathrm{c}, 2,3$, and 4 (Table 2).

Plasma urea, creatinine, and phosphate were significantly increased in study 1 a compared to studies $1 \mathrm{~b}, 1 \mathrm{c}, 2$, 3,4 , and $5(p<0.01)$. Blood $\mathrm{pH}$ was significantly decreased $(p<0.01)$ in Study 1 a compared to the other study groups (Table 1).

The basal free immunoreactive insulin concentration was significantly increased in Type 1 diabetic uraemic patients before transplantation, in all patients after transplantation, and in group 5, compared to normal subjects, control subjects on long-term steroid therapy and control subjects on long-term cyclosporin therapy $(p<0.01)$. During the clamp, the increment in plasma free immunoreactive insulin concentration was similar in all groups (Table 2).

Basal plasma glucagon concentration was higher in Type 1 diabetic-uraemic patients compared to all study groups. During the $0-120 \mathrm{~min}$ period of insulin infusion, plasma glucagon, either decreased slightly or did not change in all the study protocols (Table 2). 
Plasma growth hormone was significantly increased in study 1 a when compared to all study groups $(p<0.01)$ (Table 1).

\section{Hepatic glucose production (Fig. 2, Table 3)}

During the last $30 \mathrm{~min}$ of the basal period, hepatic glucose production of diabetic uraemic patients before transplantation was significantly higher than that observed in the remaining groups with the exception of group 5. When the insulin clamp was started, the hepatic glucose production decreased by $70 \%$ after $30 \mathrm{~min}$ in studies $1 \mathrm{~b}, 1 \mathrm{c}, 2,3$, and 4 , and was reduced by $90 \%$ after $90 \mathrm{~min}$. Study 1 a (Type 1 diabetic-uraemic subjects before transplantation) demonstrated only a $50 \%$ suppression of hepatic glucose production after $30 \mathrm{~min}$ of insulin infusion $(p<0.01)$, and $80 \%$ suppression after $90 \mathrm{~min}$ of insulinisation (Fig.2). Study 5 had a basal hepatic glucose production of $2.8 \pm$ $0.3 \mathrm{mg} \cdot \mathrm{kg}^{-1} \cdot \mathrm{min}^{-1}$, which demonstrated an $85 \%$ suppression at $80 \mathrm{~min}$ after the start of insulin infusion.

\section{Tissue glucose disposal (Fig. 3, Table 3)}

In the basal state, total body tissue glucose disappearance was $30 \%$ greater in Type 1 diabetic-uraemic subjects and in group 5 when compared to the remaining study groups. During the insulin clamp tissue glucose disposal increased slightly above baseline in study 1 a but remained markedly below the corresponding values of studies $1 \mathrm{~b}, 1 \mathrm{c}, 2,3$, and 4 (Table 3 ). Patients included in study 5 (60$120 \mathrm{~min}=4.5 \pm 0.3 \mathrm{mg} \cdot \mathrm{kg}^{-1} \cdot \mathrm{min}^{-1} ; p<0.05$ vs study $1 \mathrm{a}$; $p<0.05$ vs study 2 and 4) had a peripheral insulin sensitivity between study $1 \mathrm{a}\left(3.7 \mathrm{mg} \cdot \mathrm{kg}^{-1} \cdot \mathrm{min}^{-1}\right)$ and study 2 and $4\left(7.8-7.2 \mathrm{mg} \cdot \mathrm{kg}^{-1} \cdot \mathrm{min}^{-1}\right)$.
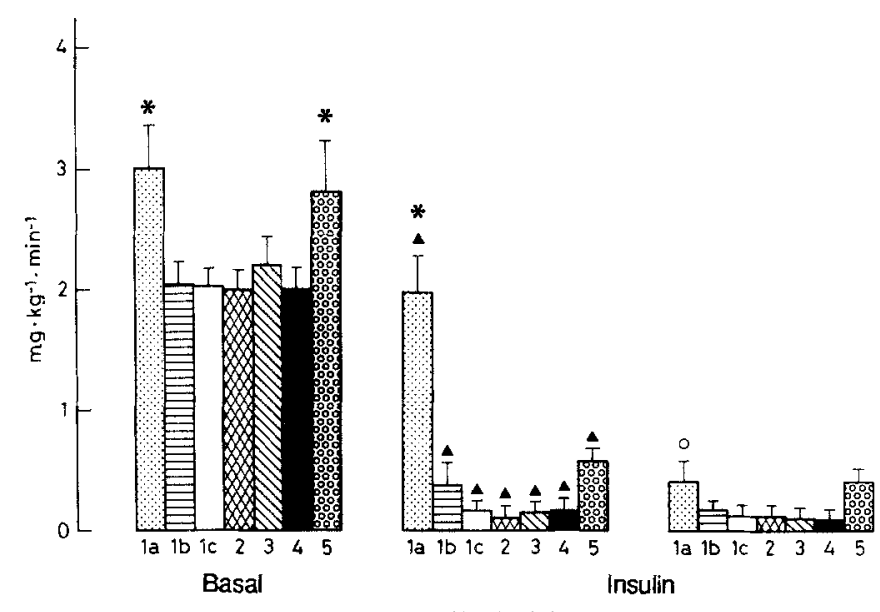

Fig. 2. Hepatic glucose production in the basal state, during the first and last $h$ of the insulin clamp in Type 1 (insulin-dependent) diabetic subjects before $(1 \mathrm{a}, 7), 4$ months $(1 \mathrm{~b}, \mathrm{G})$ and 12 months after transplantation (1c, $\square$ ); in normal subjects $(2$, ), control subjects on long-term steroid therapy $(3, \mathbb{N})$, control subjects on long-term cyclosporin therapy $(4, \square)$ and in Type 1 (insulin-dependent) diabetic subjects with isolated kidney transplantation (5, cates $p<0.01$ vs Studies 1 b, 1c, 2, 3, and 4; $\boldsymbol{\Delta}$ indicates $p<0.001$ vs basal; $O$ represents $p<0.01$ vs the $0-60 \mathrm{~min}$ period. The height of each bar represents the mean $\pm \mathrm{SEM}$

\section{Oxidative glucose disposal (Table 3)}

In the post-absorptive diabetic uraemic subjects glucose oxidation was similar to all the remaining groups. In response to insulin (60-120 min of the clamp) both the absolute rate of glucose oxidation (Table 3 ), as well as the percentage increase in glucose oxidation above baseline, were reduced in study 1 a ( $30 \%)$ compared to studies $1 \mathrm{~b}$

Table 3. Values of hepatic glucose production, tissue glucose disposal and substrate oxidation rate in the basal state and during the last h of the insulin clamp. All the numbers represent the mean \pm SEM of measures taken in the last 30 min of the basal period (Bas) and of the $60-120$ min period of the insulin clamp (Ins)

\begin{tabular}{|c|c|c|c|c|c|c|c|c|c|c|c|c|c|c|}
\hline \multirow[t]{2}{*}{ Groups } & \multicolumn{2}{|c|}{$\begin{array}{l}\text { 1a } \\
\text { Type } 1 \text { dia- } \\
\text { betic patients } \\
\text { (pre-tpx) }\end{array}$} & \multicolumn{2}{|c|}{$\begin{array}{l}1 \mathrm{~b} \\
\text { Type } 1 \text { diabetic } \\
\text { patients (post- } \\
\text { tpx) ( } 4 \text { months) }\end{array}$} & \multicolumn{2}{|c|}{$\begin{array}{l}\text { Ic } \\
\text { Type } 1 \text { diabetic } \\
\text { patients (post- } \\
\text { tpx) (12 months) }\end{array}$} & \multicolumn{2}{|c|}{$\begin{array}{l}2 \\
\text { Normal } \\
\text { subjects }\end{array}$} & \multicolumn{2}{|c|}{$\begin{array}{l}3 \\
\text { Control subjects } \\
\text { (long-term ste- } \\
\text { roid therapy) } \\
\end{array}$} & \multicolumn{2}{|c|}{$\begin{array}{l}4 \\
\text { Control subjects } \\
\text { (long-term cyclo- } \\
\text { sporin therapy) }\end{array}$} & \multicolumn{2}{|c|}{$\begin{array}{l}5 \\
\text { Type } 1 \text { diabetic } \\
\text { patients (isolated } \\
\text { kidney tpx) }\end{array}$} \\
\hline & Bas & Ins & Bas & Ins & Bas & Ins & Bas & Ins & Bas & Ins & Bas & Ins & Bas & Ins \\
\hline $\begin{array}{l}\text { Hepatic giucose } \\
\text { production } \\
\left(\mathrm{mg} \cdot \mathrm{kg}^{-1} \cdot \min ^{-1}\right)\end{array}$ & $\begin{array}{l}3.0 \pm \\
0.2^{\mathrm{b}}\end{array}$ & $\begin{array}{l}0.4 \pm \\
0.1\end{array}$ & $\begin{array}{l}2.1 \pm \\
0.2\end{array}$ & $\begin{array}{l}0.2 \pm \\
0.1\end{array}$ & $\begin{array}{l}2.0 \pm \\
0.1\end{array}$ & $\begin{array}{l}0.1 \pm \\
0.1\end{array}$ & $\begin{array}{l}2.0 \pm \\
0.2\end{array}$ & $\begin{array}{l}0.1 \pm \\
0.1\end{array}$ & $\begin{array}{l}2.2 \pm \\
0.4\end{array}$ & $\begin{array}{l}0.2 \pm \\
0.1\end{array}$ & $\begin{array}{l}2.0 \pm \\
0.2\end{array}$ & $\begin{array}{l}0.1 \pm \\
0.1\end{array}$ & $\begin{array}{l}2.8 \pm \\
0.3^{b}\end{array}$ & $\begin{array}{l}0.4 \pm \\
0.1\end{array}$ \\
\hline $\begin{array}{l}\text { Total tissue glucose } \\
\text { disposal } \\
\left(\mathrm{mg} \cdot \mathrm{kg}^{-1} \cdot \mathrm{min}^{-1}\right)\end{array}$ & $\begin{array}{l}3.0 \pm \\
0.2^{\mathrm{b}}\end{array}$ & $\begin{array}{l}3.7 \pm \\
0.3\end{array}$ & $\begin{array}{l}2.1 \pm \\
0.2\end{array}$ & $\begin{array}{l}4.7 \pm \\
0.3\end{array}$ & $\begin{array}{l}2.0 \pm \\
0.1\end{array}$ & $\begin{array}{l}6.4 \pm \\
0.5^{\mathrm{d}, \mathrm{e}}\end{array}$ & $\begin{array}{l}2.0 \pm \\
0.2\end{array}$ & $\begin{array}{l}7.8 \pm \\
0.4\end{array}$ & $\begin{array}{l}2.2 \pm \\
0.4\end{array}$ & $\begin{array}{l}6.3 \pm \\
0.4^{\mathrm{d}}\end{array}$ & $\begin{array}{l}2.0 \pm \\
0.2\end{array}$ & $\begin{array}{l}7.4 \pm \\
0.5\end{array}$ & $\begin{array}{l}2.8 \pm \\
0.3^{\mathrm{b}}\end{array}$ & $\begin{array}{l}4.5 \pm \\
0.3^{d}\end{array}$ \\
\hline $\begin{array}{l}\text { Glucose oxidation } \\
\left(\mathrm{mg} \cdot \mathrm{kg}^{-1} \cdot \mathrm{min}^{-1}\right)\end{array}$ & $\begin{array}{l}1.50 \pm \\
0.25\end{array}$ & $\begin{array}{l}1.96 \pm \\
0.24^{\mathrm{b}, t}\end{array}$ & $\begin{array}{l}1.42 \pm \\
0.25\end{array}$ & $\begin{array}{l}2.88 \pm \\
0.33\end{array}$ & $\begin{array}{l}1.52 \pm \\
0.35\end{array}$ & $\begin{array}{l}3.43 \pm \\
0.44\end{array}$ & $\begin{array}{l}1.55 \pm \\
0.15\end{array}$ & $\begin{array}{l}3.19 \pm \\
0.49\end{array}$ & $\begin{array}{l}1.36 \pm \\
0.38\end{array}$ & $\begin{array}{l}2.88 \pm \\
0.28\end{array}$ & $\begin{array}{l}1.45 \pm \\
0.10\end{array}$ & $\begin{array}{l}3.15 \pm \\
0.35\end{array}$ & $\begin{array}{l}1.55 \pm \\
0.15\end{array}$ & $\begin{array}{l}2.05 \pm \\
0.26^{\mathrm{b}, \mathrm{f}}\end{array}$ \\
\hline $\begin{array}{l}\text { Non-oxidative } \\
\text { glucose disposal } \\
\left(\mathrm{mg} \cdot \mathrm{kg}^{-1} \cdot \mathrm{min}^{-1}\right)\end{array}$ & - & $\begin{array}{l}1.74 \pm \\
0.20\end{array}$ & - & $\begin{array}{l}1.82 \pm \\
0.19^{c}\end{array}$ & - & $\begin{array}{l}2.97 \pm \\
0.22^{\mathrm{c}, \mathrm{e}}\end{array}$ & - & $\begin{array}{l}4.61 \pm \\
0.28^{\mathrm{e}}\end{array}$ & - & $\begin{array}{l}3.42 \pm \\
0.19^{\mathrm{d}, e}\end{array}$ & - & $\begin{array}{l}4.25 \pm \\
0.26^{\mathrm{e}}\end{array}$ & - & $\begin{array}{l}2.45 \pm \\
0.18^{\circ}\end{array}$ \\
\hline $\begin{array}{l}\text { Lipid oxidation } \\
\left(\mathrm{mg} \cdot \mathrm{kg}^{-1} \cdot \mathrm{min}^{-1}\right)\end{array}$ & $\begin{array}{l}0.99 \pm \\
0.16\end{array}$ & $\begin{array}{l}0.47 \pm \\
0.09^{\mathrm{d}}\end{array}$ & $\begin{array}{l}1.27 \pm \\
0.16\end{array}$ & $\begin{array}{l}0.49 \pm \\
0.07\end{array}$ & $\begin{array}{l}1.10 \pm \\
0.19\end{array}$ & $\begin{array}{l}0.18 \pm \\
0.06\end{array}$ & $\begin{array}{l}1.12 \pm \\
0.10\end{array}$ & $\begin{array}{l}0.19 \pm \\
0.07\end{array}$ & $\begin{array}{l}1.05 \pm \\
0.10\end{array}$ & $\begin{array}{l}0.28 \pm \\
0.10\end{array}$ & $\begin{array}{l}1.18 \pm \\
0.09\end{array}$ & $\begin{array}{l}0.33 \pm \\
0.05\end{array}$ & $\begin{array}{l}1.05 \pm \\
0.15\end{array}$ & $\begin{array}{l}0.52 \pm \\
0.09^{\mathrm{d}}\end{array}$ \\
\hline $\begin{array}{l}\text { Protein oxidation } \\
\left(\mathrm{mg} \cdot \mathrm{kg}^{-1} \cdot \mathrm{min}^{-1}\right)\end{array}$ & $\begin{array}{l}1.10 \pm \\
0.13^{\mathrm{a}}\end{array}$ & - & $\begin{array}{l}0.72 \pm \\
0.21\end{array}$ & - & $\begin{array}{l}0.74 \pm \\
0.10\end{array}$ & - & $\begin{array}{l}0.80 \pm \\
0.10\end{array}$ & - & $\begin{array}{l}0.75 \pm \\
0.16\end{array}$ & - & $\begin{array}{l}0.75 \pm \\
0.16\end{array}$ & - & $\begin{array}{l}0.78 \pm \\
0.09\end{array}$ & - \\
\hline
\end{tabular}

${ }^{\mathrm{a}} p<0.01$ with respect to study groups $1 \mathrm{~b}, 1 \mathrm{c}, 2,3,4$, and 5; ${ }^{\mathrm{b}} p<0.01$ with respect to study groups $1 \mathrm{~b}, 1 \mathrm{c}, 2,3$, and 4 ; ${ }^{\mathrm{c}} p<0.01 \mathrm{with}$ respect to study groups 2 and $4 ;{ }^{\mathrm{d}} p<0.05$ with respect to study groups 2 and $4 ;{ }^{\mathrm{e}} p<0.01$ with respect to group 1 a; ${ }^{\mathrm{f}} p<0.05$ with respect to the basal.

tpx $=$ transplantation 

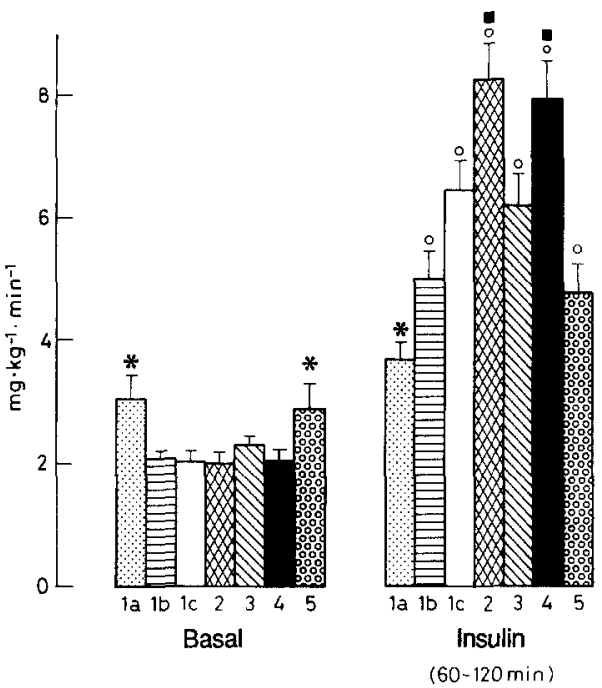

Fig. 3. Total tissue glucose disposal in the basal state, and during the last $\mathrm{h}$ of the insulin clamp in Type 1 (insulin-dependent) diabetic subjects before $(1 \mathrm{a}, 7), 4$ months $(1 \mathrm{~b}$, transplantation (1c, $\square$ ); in normal subjects $(2$, , control subjects on long-term steroid therapy $(3, \mathbb{W})$, control subjects on long-term cyclosporin therapy (4, $\mathbf{\text { ) }}$ and in Type 1 (insulin-dependent) diabetic subjects with isolated kidney transplantation (5, 哭). * indicates $p<0.01$ vs studies $1 \mathrm{~b}, 1 \mathrm{c}, 2,3$, and 4; $\mathrm{O}$ indicates $p<0.01$ vs basal; $O$ represents $p<0.05$ vs Studies $1 c$ and 3 . The height of each bar represents the mean \pm SEM

$(102 \%), 1 \mathrm{c}(126 \%), 2(106 \%), 3(112 \%)$, and $4(117 \%)$, but did not show a significant difference when compared to study $5(35 \%)$. Non-oxidative glucose disposal during the last $\mathrm{h}$ of the insulin clamp was reduced in study $1 \mathrm{~b}$, $1 \mathrm{c}$, and 3, when compared to study 2 and 4 (Table 3 ). Non-oxidative glucose disposal was significantly increased in study $1 \mathrm{c}$, when compared to study $1 \mathrm{a}$ $(p<0.01)$.

\section{Lipid and protein oxidation (Table 3)}

Basal lipid oxidation was comparable in all the study groups. Following insulin infusion, the decrease of the lipid oxidation rate was significantly less in studies $1 \mathrm{a}$ and $5(p<0.05)$ when compared to studies $1 \mathrm{~b}, 1 \mathrm{c}, 2,3,4$. In the basal state the protein oxidation rate, estimated from the nitrogen excretion was significantly increased in

Table 4. Plasma immunoreactive insulin (IRI) in the basal state (Bas), during a $75 \mathrm{~g}$ oral glucose tolerance test (OGTT) (samples taken at 60 and $120 \mathrm{~min}$ ) and during a $0.5 \mathrm{~g} \cdot \mathrm{kg}^{-1}$. body weight ${ }^{-1}$ intravenous glucose tolerance test (IVGTT) (samples taken at 3 and $30 \mathrm{~min}$ ) in patients after combined kidney-pancreas transplantation. In parentheses the respective values of normal subjects are reported

\begin{tabular}{llll}
\hline \multicolumn{4}{c}{ Plasma free IRI $(\mu \mathrm{U} / \mathrm{ml})$} \\
\hline \multirow{2}{*}{ OGTT } & Bas & $60 \mathrm{~min}$ & $120 \mathrm{~min}$ \\
& $16 \pm 4^{\mathrm{a}}(5 \pm 1)$ & $43 \pm 9(42 \pm 5)$ & $46 \pm 12^{\mathrm{a}}(28 \pm 5)$ \\
& Bas & $3 \mathrm{~min}$ & $30 \mathrm{~min}$ \\
IVGTT & $20 \pm 5^{\mathrm{a}}(6 \pm 1)$ & $42 \pm 10(50 \pm 6)$ & $43 \pm 7^{\mathrm{b}}(32 \pm 5)$ \\
\hline
\end{tabular}

a $p<0.01$ with respect to the normal subjects; ${ }^{\mathrm{b}} p<0.05$ with respect to the normal subjects study 1 a when compared to studies $1 \mathrm{~b}, 1 \mathrm{c}, 2,3,4$ and 5 (Table 3).

\section{Discussion}

Both Type 1 diabetes $[27,28]$ and chronic renal failure [29, 30] determine an impairment of insulin action. The cause of insulin resistance is multifactorial and has been related to hormonal and metabolic abnormalities [13, 31-41, 4351]. In contrast with Type 1 diabetes, in chronic renal failure high polypeptide hormone levels, are not necessarily the result of hypersecretion, but can be due to clearance defects. An important clinical consequence of the reduced insulin clearance is the diminished insulin requirement in Type 1 diabetic uraemic patients. In addition, hyperglucagonaemia of chronic renal failure is only partially accounted for by a biologically active glucagon concentration [47].

Many authors have shown that a short-term strict glycaemic control improves insulin sensitivity in Type 1 diabetic subjects [53, 54]. Haemodialysis programmes have been shown to reduce insulin resistance in patients with chronic uraemia [55]. Successful combined kidneypancreas transplantation results in continuous maintenance of normal glucose homeostasis $[7,8,56]$ and kidney function $[8,56]$. All the 15 subjects described in this study who had undergone combined kidney-pancreas transplantation had optimal glycaemic control during the two months preceding the study. After combined transplantation the patients were slightly hyperinsulinaemic both basally and following oral glucose tolerance test or intravenous glucose tolerance test (Table 4). This was probably due to the fact that after pancreatic transplantation insulin is secreted into the iliac and not into the portal vein, which leads to a condition of relative peripheral hyperinsulinaemia. All the other metabolic and hormonal parameters were in the normal range (Tables 1 and 2). Plasma glucose, blood $\mathrm{pH}$, plasma glucagon, and plasma growth hormone, were normalised after transplantation (Tables 1 and 2), eliminating some of the causes of insulin resistance previously described $[35,43$, $31,33]$. Nonetheless, the insulin-stimulated tissue glucose uptake was reduced by $25 \%$ in comparison to normal subjects (group 2). Among the drugs used in our immunosuppressive protocol, prednisone has been widely shown to impair tissue glucose disposal in vivo $[13,14]$. To test the hypothesis that the residual insulin resistance may have been due to long-term steroid therapy, we have studied group 3. During the last h of the insulin clamp, the insulin-stimulated tissue glucose disposal of control subjects on long-term steroid therapy was comparable to that of patients after combined kidney and pancreas transplantation (after one year of transplant) and was significantly lower than that in the group of normal subjects (Table 3, Fig. 3). Interestingly, the insulin-stimulated oxidative glucose disposal rates are similar in patients after transplantation, in control subjects in long-term steroid therapy, and in normal subjects (Table 3). Thus, long-term steroid therapy reduces peripheral glucose utilization essentially by impairing the glycogen synthetic 
pathway. The oxidative pathway is however unaltered. This is in agreement with the "in vivo" observation of Baron et al. who demonstrated an impaired stimulation of insulin-mediated glucose disposal and a normal noninsulin mediated glucose uptake [15].

The study of group 4 has shown that therapeutic doses of cyclosporin A have no apparent effect on insulin action in vivo (Fig. 3). Thus, we reasonably conclude that prednisone is the cause of the residual insulin resistance in our transplant patients. Cyclosporin is also known to affect renal function [57]. Only three cyclosporin-treated patients demonstrated a transient renal impairment during the study protocol, which was certainly due to cyclosporin toxicity. All the other patients had a relatively low renal toxicity because of the strict maintenance of blood cyclosporin therapeutical range $(150-300 \mathrm{ng} / \mathrm{ml})$.

Hepatic glucose production demonstrated a marked resistance to its suppression during insulin clamp in patients before pancreatic transplant, which was completely reversed at only four months after surgery (Fig.2). In many reports "pure" insulin dependent diabetic patients $[27,41]$ and "pure" uraemic patients [30], showed no insulin resistance at the liver site with a similar insulin dose. We believe that the delayed suppression of hepatic glucose production $(70 \mathrm{~min})$ may be due to the combination of diabetes and uraemia, in this study group (1 a).

Basal tissue glucose disposal was increased in studies $1 \mathrm{a}$ and 5 with respect to all groups (Table 3 ). This can be explained by the higher basal plasma glucose concentration in studies $1 \mathrm{a}$ and 5 , which may consequently enhance glucose uptake by mass action effect [41]. Expressing glucose disposal as clearance rate of glucose [41], the tissue glucose clearance would be diminished in studies $1 \mathrm{a}$ and 5 compared to all groups.

No difference was shown in the basal state between Type 1 diabetic uraemic patients and post-transplant patients as regards the lipid oxidation rate. Following insulin infusion, the decrease of lipid oxidation was significantly less in study $1 \mathrm{a}$ than in studies $1 \mathrm{~b}$ and $1 \mathrm{c}$, indicating an improvement of insulin-stimulated lipid metabolism after pancreas transplantation. The protein oxidation rate was also normalised by combined transplantation (Table 3). Although prednisone has been shown to increase protein catabolism [58-61] our prednisone-treated groups showed normal protein catabolic rates, again probably explained by the low dose of this drug administered.

The study of group 5 (Type 1 diabetic patients with isolated kidney transplant) allowed us to separate the effect of isolated kidney and isolated pancreas transplantation on insulin sensitivity. On the basis of our results we consider that both Type 1 diabetes and uraemia play a role in reducing insulin sensitivity.

\footnotetext{
Acknowledgements. We wish to thank Mrs. P.Sandoli and G.Santambrogio for their skilled technical assistance. This work was partially supported by grants from Istituto Scientifico San Raffaele and Consiglio Nazionale delle Ricerche.

Dr. L. Luzi was a recipient of the Juvenile Diabetes Foundation Fellowship \# 387179 .
}

\section{References}

1. Sutherland DER, Moudry K (1986) Pancreas transplant registry report. Transplant Proc 18: 1739-1746

2. Prieto M, Sutherland DER, Goetz FC, Rosenberg ME, Najarian JS (1987) Pancreas transplant results according to the technique of duct management: bladder versus enteric drainage. Surgery 102: 680-691

3. Dubernard JM, Traeger J, Neyra P, Touraine JL, Trenchant D, Blanc Brunat N (1978) A new method of preparation of segmental pancreatic graft for transplantation: trials in dogs and in man. Surgery 84: 633-639

4. Calne RJ (1984) Paratopic segmental pancreas grafting: a technique with portal venous drainage. Lancet I: 595-597

5. Groth GC, Collste H, Lundgren G, Wilczek H, Klintmalm G, Ringden O, Gunnarsson R, Östman J (1982) Successful outcome of segmental human pancreatic transplantation with enteric exocrine diversion after modification in technique. Lancet II: $522-524$

6. Pozza G, Traeger J, Dubernard JM, Secchi A, Pontiroli AE, Bosi E, Malik MC, Ruitton A, Blanc N (1983) Endocrine responses of Type 1 (insulin-dependent) diabetic patients following successful pancreas transplantation. Diabetologia 24: 244 248

7. Sutherland DER, Najarian JS, Greensberg BZ, Senske BJ, Anderson GE, Francis RS, Goetz FC (1981) Hormonal and metabolic effects of a pancreatic exocrine graft. Ann Int Med 95: $537-$ 541

8. Pozza G, Bosi E, Secchi A, Piatti PM, Touraine JL, Gelet A, Pontiroli AE, Dubernard JM, Traeger J (1985) Metabolic control of type 1 (insulin-dependent) diabetes after pancreas transplantation. Br Med J 291: 510-513

9. Tyden G, Wilczec H, Lundgren G, Östman J, Gunnarsson R, Jarenko F, Groth G-C (1985) Experience with 21 intraperitoneal segmental pancreatic transplants with enteric or gastric exocrine diversion in humans. Transplant Proc 17:331-335

10. Östman J, Bolinder J, Gunnarsson R, Brattström C, Tyden G, Wahren J, Groth G-C (1989) Effects of pancreas transplantation on metabolic and hormonal profiles in IDDM patients. Diabetes 38 [S 1]: $88-93$

11. Landgraf $R$, Landgraf-Leurs MMC, Burg D, Kampik A, Castro LA, Abendroth A, Illner WD, Land W (1986) Long-term follow up of segmental pancreas transplantation in Type 1 diabetes. Transplant Proc 18: 1118-1124

12. Sutherland DER (1988) Who should get a pancreas transplant? Diabetes Care 11: 681-685

13. Rizza R, Mandarino LJ, Gerich JE (1982) Cortisol induced insulin resistance in man: impaired suppression of glucose production and stimulation of glucose utilization due to a post-receptor defect in insulin action. J Clin Endocrinol Metab 54: 131-138

14. Pagano G, Cavallo-Perin P, Cassader M, Bruno A, Ozzello A, Masciola P, Dall'Omo AM, Imbimbo B (1983) An in vivo and in vitro study of the mechanism of prednisone -induced insulin resistance in healthy subjects. J Clin Invest 72: 1814-1820

15. Baron AD, Wallace P, Brechtel G (1987) In vivo regulation of non insulin-mediated and insulin-mediated glucose uptake by cortisol. Diabetes 36: 1230-1237

16. Abumrad NN, Rabin D, Diamond MP, Lacy WW (1981) Use of a heated superficial hand vein as an alternative site for the measurement of amino acid concentrations and for the study of glucose and alanine kinetics in man. Metabolism 30: 936-940

17. Thiebaud D, Jacot E, DeFronzo RA, Maeder E, Jecquier E, Felber JP (1982) Effect of graded amounts of insulin on total glucose uptake, glucose oxidation and glucose storage in man. Diabetes 31: 957-963

18. Castellino P, Luzi L, Simonson DC, Haymond WM, DeFronzo RA (1987) Effect of insulin and plasma amino acid concentrations on leucine metabolism in man. J Clin Invest 80: 1784-1793

19. DeFronzo RA, Tobin JD, Andres R (1979) Glucose clamp technique: a method for quantifying insulin secretion and resistance. Am J Physiol 232: E214-E233 
20. Steele R (1959) Influence of glucose loading and of injected insulin on hepatic glucose output. Ann NY Acad Sci 82: 420-430

21. Frayn KN (1983) Calculation of substrate oxidation rates in vivo from gaseous exchange. J Appl Physiol 55: 628-634

22. Lusk $G$ (1928) The elements of the science of nutrition. WB Saunders, Philadelphia

23. Hawk PD (1947) Kjeldhal method. In: Practical physiological chemistry 12th edn. Blakiston, Toronto, pp 814-822

24. Ripamonti M, Mosea A, Rovida E, Luzzana M, Luzi L, Ceriotti F, Cottini F, Rossi-Bernardi L (1984) Urea, creatinine and glucose determined in plasma and whole blood by a differential-pH technique. Clin Chem 30: 556-559

25. Novak M (1965) Colorimetric ultramicromethod for the determination of free fatty acids. J Lip Res 6: 431-433

26. Groop LC, Luzi L, Melander A, Groop P-H, Ratheiser K, Simonson DC, DeFronzo RA (1987) Different effects of glyburide and glipizide on insulin secretion and hepatic glucose production in normal and NIDDM subjects. Diabetes 36: 1320-1328

27. DeFronzo RA, Hendler R, Simonson DC (1982) Insulin resistance is a prominent feature of insulin-dependent diabetes. Diabetes 31:795-701

28. Del Prato S, Nosadini R, Tiengo A, Tessari P, Avogaro A, Trevisan R, Valerio A, Muggeo M, Cobelli C, Toffolo G (1983) Insulin-mediated glucose disposal in type 1 diabetes: evidence for insulin resistance. J Clin Endocrinol Metab 57:904-910

29. Mondon C, Dolkas C, Reaven G (1978) The site of insulin resistance in acute uremia. Diabetes 27:571-576

30. DeFronzo RA, Alvestrand A, Smith D, Hendler R, Wahren J (1987) Insulin resistance in uremia. J Clin Invest 79: 547-556

31. Del Prato S, Castellino P, Simonson DC, DeFronzo RA (1987) Hyperglucagonemia and insulin-mediated glucose metabolism. J Clin Invest 79: 547-556

32. Mc Gorman LR, Rizza RA, Gerich JE (1981) Physiological concentrations of growth hormone exert insulin-like and insulin antagonistic effects on both hepatic and extrahepatic tissues in man. J Clin Endocrinol Metab 53: 556-559

33. Rizza RA, Mandarino LJ, Gerich JE (1982) Effects of growth hormone on insulin action in man. Diabetes 31: 663-669

34. Deibert DC, DeFronzo RA (1980) Epinephrine-induced insulin resistance in man - a beta receptor mediated phenomenon. J Clin Invest 65: 717-721

35. Unger RH, Grundy S (1985) Hyperglycemia as an inducer, as well as a consequence of impaired islet cell function and insulin resistance: implication for the management of Diabetes. Diabetologia 28: 119-121

36. Rossetti L, Smith D, Shulman GI, Papachristou D, DeFronzo RA (1987) Correction of hyperglycemia with phloridzin normalizes tissue sensitivity to insulin in diabetic rats. J Clin Invest 79: 1510-1515

37. Tessari $P$, Inchiostro S, Biolo G, Duner E, Nosadini R, Tiengo A, Crepaldi G (1985) Hyperaminoacidaemia reduces insulinmediated glucose disposal in healthy man. Diabetologia 28: 870872

38. Balasse EO (1971) Effect of free fatty acids and ketone bodies on glucose uptake and oxidation in the dog. Horm Metab Res 3: 403-409

39. Ferrannini E, Barrett EJ, Bevilacqua S, DeFronzo RA (1983) Effect of fatty acids on glucose production and utilization in man. $\mathrm{J}$ Clin Invest $72: 1737-1747$

40. McGarry JD, Foster DW (1972) Regulation of ketogenesis and clinical aspects of the ketotic state. Metabolism 21:471-489

41. Luzi L, Barrett EJ, Groop LC, Ferrannini E, De Fronzo RA (1988) Metabolic effects of low-dose insulin therapy on diabetic ketoacidosis. Diabetes 37: 1470-1477

42. Quesniaux V, Tees R, Schreier MH, Mauer G, van Regen Moretel MHV (1987) Potential of monoclonal antibodies to improve therapeutic monitoring of cyclosporin. Clin Chem 33: 32-37

43. Ropers TA (1958) Inhibition of glucose uptake by acidosis in vitro. Proc Soc Exp Biol Med 97: 646-647
44. Bilbrey GL, Faloona GR, White MG, Knochel JP (1974) Hyperglucagonemia of renal failure. J Clin Invest 53: 841-847

45. Linn VS, Kathpalia SC, Henriquez C (1978) Endocrine abnormalities associated with chronic renal failure. Med Clin N Am 62: 1341-1344

46. Phillips LS, Kopple JD (1981) Circulating somatomedin activity and sulfate levels in adults with normal and impaired kidney function. Metabolism 30: 1091-1095

47. Emmanouel DS, Jaspan JB, Rubenstein AH, Fink AHH, Katz AI. Glucagon metabolism in the rat (1978) Contribution of the kidney to the metabolic clearance rate of the hormone. J Clin Invest 62: 6-13

48. Ringoir S, Schoots A, Vanholder R (1988) Uremic toxins. Kidney Int 33 [Suppl 24]: S4-9

49. Ferrannini E, Buzzigoli G, Bonadonna R, Giorico MA, Oleggini M, Graziadei L, Pedrinelli R, Brandi L, Bevilacqua S (1987) Insulin resistance in essential hypertension. N Engl J Med 317 350-357

50. DeFronzo RA, Felig P (1980) Amino acid metabolism in uremia: insights gained from normal and diabetic man. Am J Clin Nutr 33: 1378-1386

51. Bagdade JD (1970) Uremic lipemia. An unrecognized abnormality in tryglyceride production and removal. Ann Intern Med 126:875-881

52. May RC, Clark AS, Goheer MA, Mitch WE (1985) Specific defects in insulin-mediated muscle metabolism in acute uremia. Kidney Int 28: 490-497

53. Yki-Järvinen H, Koivisto V (1984) Continuous subcutaneous insulin infusion therapy decreases insulin resistance in type 1 diabetes. J Clin Endocrinol Metab 58: 659-666

54. Garvey WT, Olefsky JM, Griffin J, Hamman RF, Koltermann OG (1985) The effect of insulin treatment on insulin secretion and insulin action in type 2 diabetes mellitus. Diabetes 34: 222-234

55. DeFronzo RA, Tobin JD, Rowe JW, Andres R (1978) Glucose intolerance in uremia. Quantification of pancreatic $\beta$-cell sensitivity to glucose and tissue sensitivity to insulin. J Clin Invest 62 : $425-435$

56. La Rocca E, Dubernard JM, Samseverino R, Camozzi L, Faure JL, Lefrancois N, Martin X, Finaz J, Touraine JL (1987) Results of simultaneous pancreaticorenal transplantation Lyon, France. Transplant Proc 19 [Suppl 4]: 44-47

57. Myers BD (1986) Cyclosporin nephrotoxicity. Kidney Int 30: 1964-1974

58. Gelfand AR, Matthews DM, Bier DM, Sherwin RS (1984) Role of counterregulatory hormones in the catabolic response to stress. J Clin Invest 74: 2238-2248

59. Tomas FN, Munro HN, Young VR (1979) Effect of glucocorticoid administration on the rate of muscle protein breakdown in vivo in rats, as measured by urinary excretion of $\mathrm{N}$-methylhistidine. Biochem J 178: 139-146

60. Baxter JD (1976) Glucocorticoid hormone action. Pharmacol Ther 2: 605-625

61. Cigolini M, Smith U (1979) Human adipose tissue in culture. VIII. Studies on the insulin-antagonistic effect of glucocorticoids. Metabolism 28:502-510

Received: 4 September 1989

and in final revised form: 26 March 1990

Dr. L. Luzi

S. Raffaele Scientific Institute

Radioactive and Stable Isotopes Laboratory

University of Milan

Via Olgettina 60

I-20132 Milano

Italy 